\title{
LETTERS
}

\section{Fibroblastic rheumatism: a Scandinavian case report}

\author{
J K Pedersen, T Poulsen, K Hørslev-Petersen
}

Ann Rheum Dis 2005;64:156-157. doi: 10.1136/ard.2003.008441

$\mathrm{F}$ ibroblastic rheumatism (FR) is a rare disorder of unknown cause first described in $1980 .{ }^{1}$ We here report the first Scandinavian patient with FR.

\section{CASE REPORT}

A 55 year old Danish woman was referred to our department in July 2000 with a $2 \frac{1}{2}$ year history of pain in the proximal interphalangeal (PIP) joints, knees, and ankles. The pain worsened over night and upon exercise. On examination, the right knee and the second PIP joint on the left hand were tender and swollen. The other PIP joints and both wrists were tender. On both hands there were several pink, 3-10 mm, tender and mobile skin nodules (fig 1 ), and a $20 \mathrm{~mm}$ nodule under the left foot.

All laboratory investigations were normal, including erythrocyte sedimentation rate, $\mathrm{C}$ reactive protein, haemoglobin, white blood cell count, platelets, and differential count. IgM rheumatoid factor, antinuclear antibodies and antineutrophil cytoplasmic antibodies were not found. An

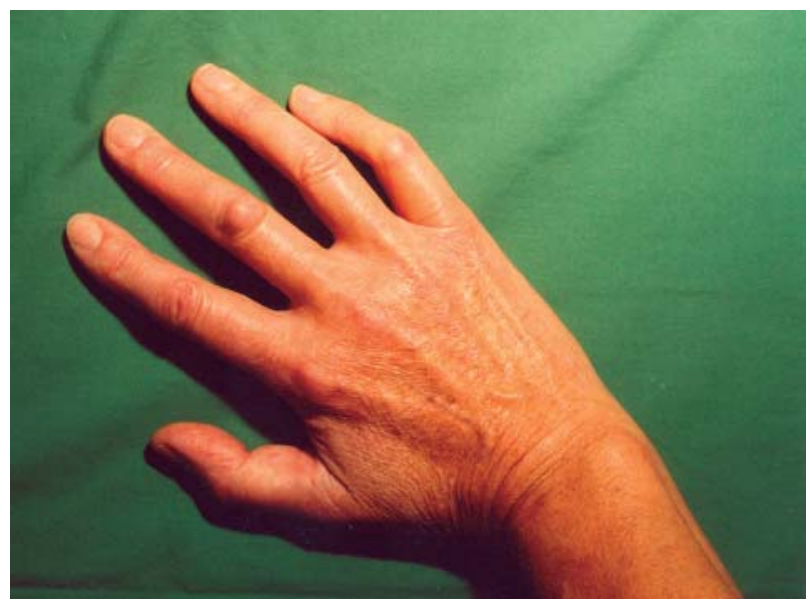

Figure 1 Skin nodules adjacent to the second metacarpophalangeal, distal interphalangeal, and third PIP joints on the right hand.

$x$ ray examination of the hands demonstrated osteoarthritis of the distal interphalangeal joints.

Two skin nodules were removed and examined by light microscopy (fig 2): they showed areas with densely packed uniform spindle cells surrounded by bundles of thickened collagen fibres and vascular granulation tissue. The biopsy specimens were without inflammatory cells, histiocytes, giant cells, granulomas, or foreign bodies. Special staining did not disclose any elastic fibres. Immunochemical staining of paraffin sections for myofibroblasts was positive for vimentin, but negative for desmin and $\alpha$-smooth muscle actin.

Treatment with celecoxib and physical therapy was started but had no effect on the symptoms.

On follow up in 2003, the patient had severe, intermittent arthralgia and she was unable to work. She had a nodular thickening of the palmar aponeurosis and a slight contracture of the fingers on both hands. $x$ Ray findings of her hands had not changed.

\section{DISCUSSION}

The diagnosis FR was based on the presence of skin nodules, joint symptoms, histopathological features, a poor outcome, and the absence of another diagnosis that could explain these characteristics. There was no evidence of systemic sclerosis, and the patient did not fulfil classification criteria for rheumatoid arthritis. ${ }^{2}$ The hallmark of multicentric reticulohistiocytosis is giant cells of a foreign body type and histiocytes in pathological specimens. ${ }^{3}$ These features were absent in both skin biopsy specimens.

With the present case included, FR has been described in a total of 18 adults and four children (table 1$).{ }^{4-7}$

The presenting symptom in FR may be joint symptoms or skin nodules, but the presence of both is pivotal for the diagnosis. A polyarthritis in small joints is often described, but a monarthritis affecting large joints may also be seen. Subcutaneous nodules have been noticed in almost every area of the skin. They are pink or flesh coloured, 2-30 mm, and sometimes surrounded by an erythema. Some patients have a diffuse swelling of the hands, and some develop a thickening of the palmar fascia.

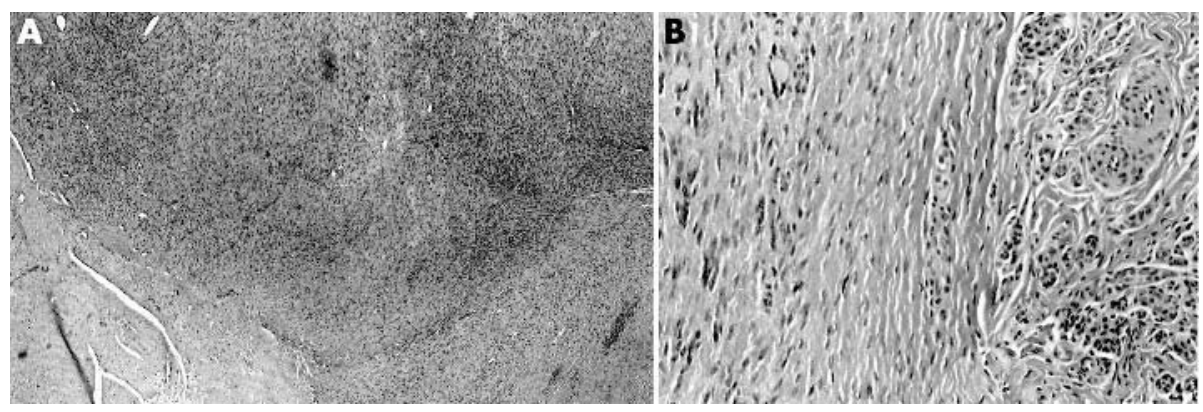

Figure 2 (A) Haematoxylin and eosin stain of a skin nodule showing a cellular area surrounded by vascular granulation tissue ( $\times 40)$. (B) Densely packed uniform spindle cells surrounded by bundles of thickened collagen fibres $(\times 100)$ 
Table 1 Features reported at presentation or follow up in 22 patients with fibroblastic rheumatism

\begin{tabular}{|c|c|c|c|}
\hline & $\begin{array}{l}\text { Reported } \\
\text { cases* }^{*}\end{array}$ & $\begin{array}{l}\text { Our } \\
\text { patient }\end{array}$ & $\begin{array}{l}\text { Total No } \\
\text { of cases } \\
(\%)\end{array}$ \\
\hline Female & 10 & + & $11(50)$ \\
\hline \multicolumn{4}{|l|}{ Musculoskeletal } \\
\hline Arthritis or arthralgia & 20 & + & $21(96)$ \\
\hline Contracture of fingers & 20 & + & $21(96)$ \\
\hline Periarticular osteopenia & 10 & - & $10(46)$ \\
\hline Erosions & 9 & - & $9(41)$ \\
\hline Myalgia & 2 & - & $2(9)$ \\
\hline \multicolumn{4}{|l|}{ Skin } \\
\hline Nodules & 21 & + & $22(100)$ \\
\hline Thickened palmar fascia & 10 & + & $11(50)$ \\
\hline \multicolumn{4}{|l|}{ Skin pathology } \\
\hline Fibroblastic proliferation & 21 & + & $22(100)$ \\
\hline Thickened collagen fibres & 21 & + & $22(100)$ \\
\hline Decreased elastic fibres & 10 & + & $11(50)$ \\
\hline Myofibroblasts & 9 & + & $10(46)$ \\
\hline \multicolumn{4}{|l|}{ Other features } \\
\hline Raynaud's phenomenon & 8 & - & $8(36)$ \\
\hline Transient fever & 8 & - & $8(36)$ \\
\hline Raised ESR & 8 & - & $8(36)$ \\
\hline
\end{tabular}

Blood tests are not diagnostic and initial $x$ ray examination of the affected joints is usually normal. Although being nonspecific, light microscopy of nodules have shown a consistent pattern in all published cases (table 1). Occasionally, myofibroblasts ${ }^{8}$ have been verified.

Nearly all patients with FR have been treated with either oral glucocorticoids, non-steroidal anti-inflammatory drugs, or disease modifying antirheumatic drugs. With different drugs, there have been reports that skin lesions are healed and the number of painful or swollen joints reduced or stabilised. However, nearly all patients, irrespective of age, end up with contractures of the fingers and, a small number, with a destructive arthropathy. To our knowledge, complete remission has only been described in two patients treated with glucocorticoids ${ }^{9}$ and low dose methotrexate. ${ }^{10}$ This may indicate that, so far, only the natural history of FR has been studied.

\section{Authors' affiliations}

J K Pedersen, K Hørslev-Petersen, Kong Christian X's Gigthospital, Department of Rheumatology, Toldbodgade 3, 6300 Graasten, Denmark

T Poulsen, Department of Pathology, Sønderborg Hospital, Sydvang 1, 6400 Sønderborg, Denmark

Correspondence to: Associate Professor K Hørslev-Petersen; khorslevpetersen@gigfforeningen.dk

Accepted 9 May 2004

\section{REFERENCES}

1 Chaouat $Y$, Aron-Brunetière $R$, Faures B, Binet $O$, Ginet $C$, Aubart D. Une novelle entité: le rhumatisme fibroblastique. A propos d'une observation. Rev Rhum Mal Osteoartic 1980;47:345-51

2 Arnett FC, Edworthy SM, Bloch DA, McShane DJ, Fries JF, Cooper NS, et al. The American Rheumatism Association 1987 revised criteria for the classification of rheumatoid arthritis. Arthritis Rheum 1988;31:315-24.

3 Campbell DA, Edwards NL. Multicentric reticulohistiocytosis: systemic macrophage disorder. Baillieres Clin Rheumatol 1991;5:301-19.

4 Lee JM, Sundel RP, Liang MG. Fibroblastic rheumatism: case report and review of the literature. Pediatr Dermatol 2002;19:532-5.

5 Fam AG, Hanna W, Mak V, Assaad D. Fibroblastic rheumatism: clinical and histologic evolution of cutaneous manifestations. J Rheumatol 1998;25:2261-6.

6 Chkirate B, Job-Deslandre C. Rhumatisme fibroblastique: à propos d'un cas. Arch Pediatr 2001;8:389-92.

7 Colonna L, Barbieri C, Di Lella G, Zambruno G, Annessi G, Puddu P. Fibroblastic rheumatism: a case without rheumatological symptoms. Acta Derm Venereol 2002;82:200-3.

8 Gabbiani G. The biology of the myofibroblast. Kidney Int 1992;41:530-2.

9 Lévigne V, Perrot JL, Faisant M, Deville V, Claudy AL. Rhumatisme fibroblastique. Ann Dermatol Venereol 1990;117:199-202.

10 Vittecoq O, Mejiad O, Da Silva F, Joly P, Thomine E, Lauret P, et al. Preliminary experience with low-dose methotrexate in fibroblastic rheumatism. Arthritis Rheum 1996;39:2070-3.

\title{
Juvenile idiopathic arthritis associated with autoimmune hepatitis type 2
}

\author{
V Nobili, R Devito, D Comparcola, E Cortis, M R Sartorelli, M Marcellini
}

J uvenile idiopathic arthritis (JIA) is one of the most common chronic disorders in childhood and affects 1 in 1000 children. $^{1}$

Recently, the International League of Associations for Rheumatology proposed consensus criteria for the classification of childhood arthritis under the term JIA. ${ }^{2}$ JIA defines an arthritis developing in patients aged 16 years or younger that has no known cause.

Liver disturbance, although not characteristic of JIA, is common and it has been attributed not only to the liver disease associated with rheumatoid diseases themselves but also to many other factors, such as fatty infiltration, drug toxicity, thrombotic accidents, or autoimmune liver disease. $^{34}$

Autoimmune hepatitis (AIH) is an unresolving inflammation of the liver of unknown cause. ${ }^{5}$ AIH type 2 (AIH 2) is characterised by the presence of anti-liver kidney microsomal autoantibodies (LKM-1) directed against cytochrome P450IID6. ${ }^{6}$ Early recognition of the disease and prompt institution of treatment are essential to avoid progression to subacute hepatic failure and the possible need for liver transplantation.

We report an unusual association-namely, a case of severe AIH type 2 in a girl with JIA.

\section{CASE REPORT}

An 8 year old girl was referred to our paediatric rheumatology clinic in June 2003 for assessment of possible JIA because of fever and joint disease affecting the right knee, with synovitis confirmed by ultrasound examination.

At admission she had laboratory evidence of a vigorous response in the acute phase with high erythrocyte 


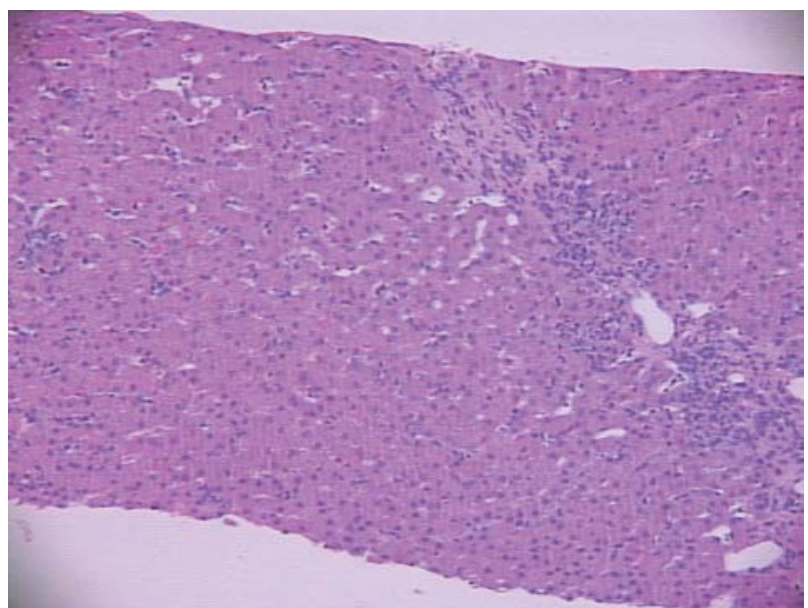

Figure 1 Autoimmune hepatitis: portal and periportal

lymphoplasmocytic inflammation with hepatitis at the portalparenchymal interface (active interface hepatitis). Magnification $\times 20$.

sedimentation rate and C reactive protein concentration, neutrophilia, and thrombocytosis. Aminotransferases (alanine aminotransferase (ALT) 123 IU/l, aspartate aminotransferase (AST) 87 IU/l, normal value 5-40 IU/l) were increased, and hypergammaglobulinaemia ( $27 \mathrm{~g} / \mathrm{l})$ and increased serum $\operatorname{IgG}(18.00 \mathrm{~g} / \mathrm{l})$ were detected. The indirect immunofluorescence method showed high titres of circulating antinuclear antibodies (ANA; 1/640) and anti-liver/kidney microsomal antibodies (LKM-1; 1/160), whereas anti-smooth muscle antibodies (ASMA), and antimitochondrial antibodies (AMA) were absent. The child's HLA haplotype was A2, B8, DR3, DRw52, DQ2, and the family history was unremarkable for autoimmune diseases.

The girl was discharged after 6 days in hospital with a diagnosis of JIA, on oral non-steroidal anti-inflammatory treatment and physiotherapy (to maintain normal joint range and muscle power).

When seen again, 6 weeks later, her clinical improvement continued but aminotransferases (ALT 123 IU/l, AST 87 IU/l) were still increased, and hypergammaglobulinaemia (26 g/l) and increased serum IgG (16.90 g/l) persisted.

Hepatitis A, B, C, D, E, and G, cytomegalovirus, and Epstein-Barr virus infections were ruled out by appropriate tests, which included serum HBV-DNA and HCV-RNA. High titres of ANA (1/640) and anti-LKM-1 antibodies persisted, whereas ASMA and AMA were absent. A percutaneous liver biopsy $^{7}$ was performed and disclosed hepatitis with bridging necrosis and features consistent with autoimmune hepatitis (portal and periportal lymphoplasmocytic inflammation, active hepatitis at the portal-parenchymal interface, bridging, and spotty necrosis) (fig 1). The diagnosis of AIH type 2 was confirmed and characterised as "definite" by using the scoring system of the International Autoimmune Hepatitis

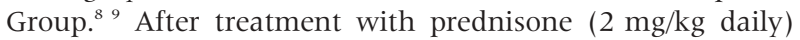
and azathioprine $(2 \mathrm{mg} / \mathrm{kg}$ daily) AST and ALT concentrations returned to normal in 5 weeks and striking reduction of immunoglobulin levels and IgG (0.96 g/l) were seen.

\section{DISCUSSION}

The diagnosis of AIH in children with JIA is of paramount importance to guiding treatment and formulating prognosis. Mild abnormalities in liver function tests are common in children with JIA; as few of them undergo liver biopsy, AIH might go undetected.

In conclusion, we believe, in according with Kojima and coworkers ${ }^{10}$ that liver histology is warranted in differentiating AIH from liver disease associated with rheumatoid disease and must be performed in all children affected by rheumatoid disease associated with persistent alterations in liver function tests.

\section{Authors' affiliations \\ V Nobili, D Comparcola, M R Sartorelli, M Marcellini, Department of Liver Diseases, Research Institute, Bambino Gesu' Children's Hospital, Rome, Italy \\ R Devito, Department of Pathology, Research Institute, Bambino Gesu' Children's Hospital, Rome, Italy \\ E Cortis, Department of Paediatric Rheumatology, Research Institute, Bambino Gesu' Children's Hospital, Rome, Italy}

Correspondence to: DrV Nobili, Department of Liver Disease, Research Institute, Bambino Gesu' Children's Hospital, Piazza S Onofrio 4, 00165 Rome, Italy; v.nobili@libero.it

Accepted 7 April 2004

\section{REFERENCES}

1 Gare BA. Epidemiology. Baillieres Clin Rheumatol 1998;12:191-208.

2 Petty RE, Southwood TR, Baum J, Bhettay E, Glass DN, Manners P, et al. Revision of the proposed classification criteria for juvenile idiopathic arthritis: Durban 1997. J Rheumatol 1998;25:1991-4.

3 Runyon BA, Labreque DR, Anuras S. The spectrum of liver disease in systemic lupus erythematosus: report of 33 histologically proved cases and review of the literature. Am J Med 1980;69:187-94.

4 Leggett BA. The liver in systemic lupus erythematosus. J Gastroenterol Hepatol 1993;8:84-8.

5 Czaja AJ. Autoimmune hepatitis: evolving concepts and treatment strategies. Dig Dis Sci 1995:40:435-56.

6 Manns MP, Griffin KJ, Sullivan KF, Johnson EF. LKM-1 autoantibodies recognize a short linear sequence in P450IID6, a cytochrome P-450 monooxygenase. J Clin Invest 1991;88:1370-8.

7 Nobili V, Comparcola D, Sartorelli MR, Natali G, Monti L, Falappa P, et al. Blind and ultrasound-guided percutaneous liver biopsy in children. PaediatrRadiol 2003;33:772-5.

8 International Autoimmune Hepatitis Group. Review of criteria for diagnosis of autoimmune hepatitis. J Hepatol 1999;31:929-38.

9 Gregorio GV, Portmann B, Reid F, Donaldson PT, Doherty DG, McCartney M, et al. Autoimmune hepatitis in childhood: a 20-year experience. Hepatology 1997;25:541-7.

10 Kojima H, Uemura M, Sakuray S, Ann T, Ishii Y, Imazu H, et al. Clinical features of liver disturbance in rheumatoid diseases: clinicopathological study with special reference to the cause of liver disturbance. J Gastroenterol 2002;37:617-25. 


\title{
Absence of fetal cell microchimerism in cutaneous lesions of lupus erythematosus
}

\author{
K Khosrotehrani, L Mery, S Aractingi, D W Bianchi, K L Johnson
}

Ann Rheum Dis 2005;64:159-160. doi: 10.1136/ard.2003.020297

$\mathrm{F}$ etal cell microchimerism develops in all human pregnancies $^{1}$ and has been associated with autoimmune diseases such as systemic sclerosis. ${ }^{2}$ It has been suggested that these disorders may be the consequence of an immune reaction between fetal and maternal cells in women after pregnancy. More recently, results from our laboratory suggest that microchimeric cells of fetal origin may differentiate into thyrocytes ${ }^{3}$ or hepatocytes ${ }^{4}$ in thyroid and liver specimens from women with non-autoimmune diseases. We therefore developed an alternative hypothesis suggesting that microchimeric stem cells may have the ability to participate in the maternal response to tissue injury. ${ }^{5}$

Systemic lupus erythematosus (SLE) is an autoimmune disease that predominantly affects women and can target multiple organ systems with severe life threatening complications. In some patients, however, lupus is limited to skin involvement, with discoid or subacute cutaneous lesions, and few of these patients develop severe disease. ${ }^{6}$ Mosca et al recently reported that the number of microchimeric cells found in patients with lupus nephritis was higher than in lupus patients without nephritis. ${ }^{7}$ Their results suggest that the severity of the disease may influence the level of fetal cell microchimerism.

\section{METHODS AND RESULTS}

To further investigate the relationship between fetal cell microchimerism and SLE, we examined biopsy specimens of affected skin from women with previous male pregnancies affected with lupus as well as other skin disorders for the presence of male microchimeric cells. Affected skin sections from six patients with lupus erythematosus (five cases of systemic and one case of cutaneous lupus) and four patients with dermatomyositis or mycosis fungoides (table 1), all with at least one male pregnancy, were analysed for the presence of microchimeric male cells by fluorescence in situ hybridisation (FISH) using probes specific for the $\mathrm{X}$ and $\mathrm{Y}$ chromosomes. Between three and six sections were examined from each subject and the scoring was blinded according to the diagnosis or the pregnancy history of the patients. No microchimeric male cells were detected in any tissue sections from these subjects. More than $90 \%$ of the nuclei had two detectable X chromosome signals (fig 1). We also examined skin sections from six women with no history of a male pregnancy; these sections also had no detectable male cells. Both $X$ and $Y$ chromosome signals were detected in $>90 \%$ of nuclei from male control tissue.

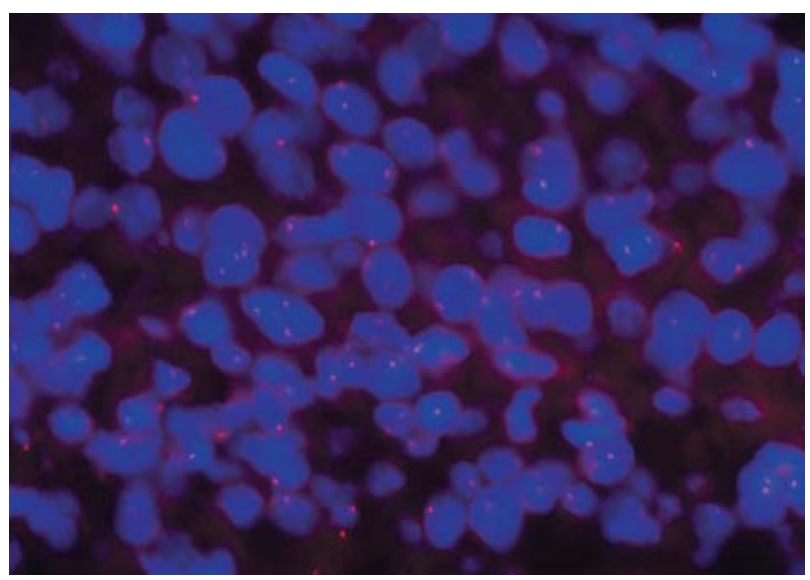

Figure 1 FISH analysis of epidermal keratinocytes. Two X chromosome signals (red) are detected in almost all cells at $\times 400$ magnification. As all chromosome signals may not be in the same plane of focus, some cells appear to have only one $X$ chromosome. No evidence of a $Y$ chromosome signal (green) was found in any female tissue examined.

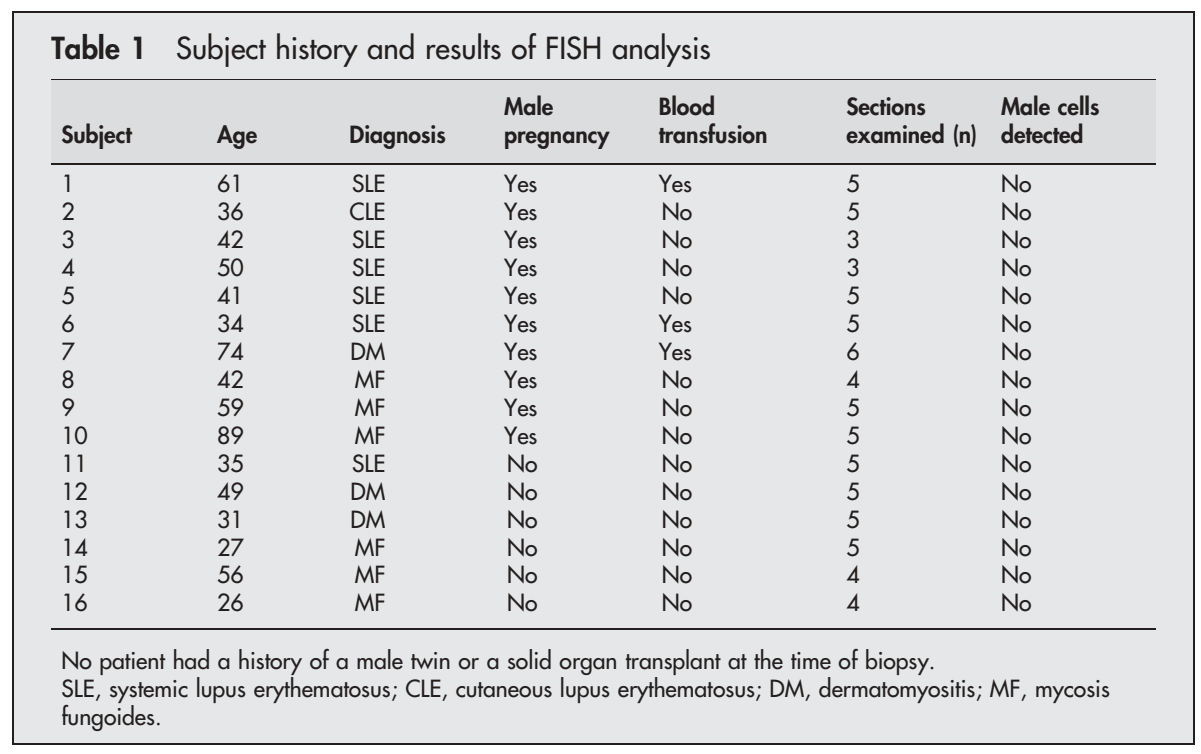




\section{DISCUSSION}

The results presented here support the findings of other studies that have reported the lack of an association between fetal cell microchimerism and SLE. ${ }^{8}$ Recently, we reported the case of a woman with severe SLE and demonstrated the presence of large numbers of male cells, presumably of fetal origin, in necropsy specimens from her clinically affected tissues. ${ }^{10}$ This patient had a severe vasculitis and ultimately died of intestinal necrosis and perforation. In contrast, all of the patients in the present study were alive, underwent skin biopsies, and had better prognoses than the case in our previously published report.

Possibly, the cases of cutaneous and moderate systemic lupus in the current study do not cross the threshold of disease severity to recruit microchimeric cells to areas of tissue damage. Therefore, the results of the present study combined with those of our previous case report support the findings by Mosca et al and suggest that extensive maternal tissue damage may be required for the development of microchimerism in cases of SLE.

\section{ACKNOWLEDGEMENT}

Dr Khosrotehrani was supported by the "Fondation René Touraine pour la recherche en dermatologie" in Paris, France.

\section{Authors' affiliations}

K Khosrotehrani, D W Bianchi, K L Johnson, Division of Genetics, Departments of Pediatrics and Obstetrics and Gynecology, Tufts-New England Medical Center, Boston, USA

L Mery, S Aractingi, Department of Dermatology, Tenon Hospital, Paris, France
Correspondence to: Professor K L Johnson, Division of Genetics,

Department of Pediatrics, Tufts-New England Medical Center, Box 394, 750 Washington Street, Boston, MA 02111 USA; kjohnson@ tufts-nemc.org

Accepted 10 March 2004

\section{REFERENCES}

1 Ariga $\mathrm{H}$, Ohto $\mathrm{H}$, Busch MP, Imamura S, Watson R, Lee W, et al. Kinetics of fetal cellular and cell-free DNA in the maternal circulation during and after pregnancy: implications for noninvasive prenatal diagnosis. Transfusion 2001;41:1524-30.

2 Nelson JL, Furst DE, Maloney S, Gooley T, Evans PC, Smith A, et al. Microchimerism and HLA-compatible relationships of pregnancy in scleroderma. Lancet 1998:351:559-62.

3 Srivatsa B, Srivatsa S, Johnson KL, Samura O, Lee SL, Bianchi DW. Microchimerism of presumed fetal origin in thyroid specimens from women: a case-control study. Lancet $2001 ; 358: 2034-8$.

4 Johnson KL, Samura O, Nelson JL, McDonnell M, Bianchi DW. Significant fetal cell microchimerism in a nontransfused woman with hepatitis $C$ : evidence of long-term survival and expansion. Hepatology 2002;36:1295-7.

5 Khosrotehrani K, Bianchi DW. Fetal cell microchimerism: helpful or harmful to the parous woman? Curr Opin Obstet Gynecol 2003;15:195-9.

6 Ruiz-Irastorza G, Khamashta MA, Castellino G, Hughes GRV. Systemic lupus erythematosus. Lancet 2001;357:1027-32.

7 Mosca M, Curcio M, Lapi S, Valentini G, D’Angelo S, Rizzo G, et al. Correlations of $Y$ chromosome microchimerism with disease activity in patients with SLE: analysis of preliminary data. Ann Rheum Dis 2003;62:651-4.

8 Ohtsuka T, Miyamoto Y, Yamakage A, Yamazaki S. Quantitative analysis of microchimerism in systemic sclerosis skin tissue. Arch Dermatol Res 2001;293:387-91.

9 Miyashita $Y$, Ono M, Ono M, Ueki H, Kurasawa K. Y chromosome microchimerism in rheumatic autoimmune disease. Ann Rheum Dis 2000:59:655-6.

10 Johnson KL, McAlindon TE, Mulcahy E, Bianchi DW. Microchimerism in a female patient with systemic lupus erythematosus. Arthritis Rheum 2001;44:2107-11.

\section{Diagnostic value of anti-cyclic citrullinated peptide antibodies to detect rheumatoid arthritis in patients with Sjögren's syndrome}

\section{C van Noord, H Hooijkaas, B C M Dufour-van den Goorbergh, P M van Hagen, P L A van Daele, J P van de Merwe}

S jögren's syndrome (SS), prevalence $3-4 \%,{ }^{1}$ is a chronic autoimmune disorder characteristically affecting the salivary and lachrymal glands. Rheumatoid arthritis (RA), prevalence $1-4 \%$, is a chronic inflammatory autoimmune disease. ${ }^{2}$

The diagnosis of RA relies mainly on clinical manifestations and serological markers such as rheumatoid factors (RF). The sensitivity of RF in RA is $75 \%$ and the specificity $74 \%{ }^{3}$ Furthermore, RF is positive in $40-70 \%$ of patients with primary SS. ${ }^{4}$ Many patients with primary SS and chronic polyarthritis consequently have RF without ever developing RA. An enzyme linked immunosorbent assay (ELISA) test has been developed that recognises a cyclic variant of a citrullinated peptide (CCP). ${ }^{2}$ The sensitivity of the first generation anti-CCP test in RA ranges from 41 to $68 \%,{ }^{5}{ }^{6}$ the sensitivity of the second generation is $82 \%{ }^{7}$ The specificity, however, is $96-98 \% .^{35-7}$

We analysed data from 164 patients who were diagnosed as SS according to the revised version of the European criteria. ${ }^{8}$ These criteria allow a diagnosis of SS if at least four items out of six or three objective items are present. Unfortunately, no single laboratory test is sufficiently reliable to confirm a clinical diagnosis of SS. ${ }^{9}$ Therefore, a second group was assembled with patients in whom three items were present and in whom no other disease could explain the sicca symptoms. This group is further referred to as Sjögren's-like syndrome.

The medical records from all patients were further investigated for RA, according to the 1987 revised criteria. ${ }^{10}$ $\mathrm{RF}$ and anti-CCP antibodies were determined in the same serum samples using the ELISA anti-CCP mark 2 (second generation) kits from Immunoscan RA, Euro-Diagnostica $A B$ (Arnhem, Netherlands) and the IgM RF ELISA test. All the data were analysed using the SPSS/PC software, version 11.0.

Table 1 shows that both groups were similar. Furthermore, it shows that anti-CCP has a high specificity (98.8\%), in contrast with the low specificity of RF $(60.6 \%)$.

The diagnostic value of the RF test in patients with SS is questionable because of its low specificity (60.6\%) in such patients. In this study we found a specificity of $98.8 \%$ for anti-CCP in the SS population for RA. The major strength of these data is to emphasise the fact that anti-CCP is not present in patients with primary SS who do not have RA, in contrast with the high prevalence of RF in patients with primary SS. 


\begin{tabular}{|c|c|c|c|}
\hline Characteristic & $\begin{array}{l}\text { All patients }(n=164) \\
(\geqslant 3 \mathrm{SS} \text { items) }\end{array}$ & $\begin{array}{l}\text { SS }(n=108) \\
(\geqslant 4 \text { SS items) }\end{array}$ & $\begin{array}{l}\text { SS-like syndrome ( } n=56) \\
\text { ( } 3 \text { SS items) }\end{array}$ \\
\hline Age (years), mean (range) & $56.3(20.1-87.3)$ & $57.1(24.9-87.3)$ & $54.6(20.1-81.9)$ \\
\hline \multicolumn{4}{|l|}{ Follow up } \\
\hline Years & 855.8 & 627.0 & 225.4 \\
\hline Median & 3.65 & 4.30 & 2.75 \\
\hline Range & $0-21.6$ & $0-21.6$ & $0.2-15.9$ \\
\hline Anti-SSA/Ro, No (\%) & $94(57)$ & 77 (71) & $17(30)$ \\
\hline Anti-SSB/La, No (\%) & 71 (43) & $62(57)$ & $9(16)$ \\
\hline RF, No (\%) & $67(41)$ & $52(48)$ & $15(27)$ \\
\hline Anti-CCP, No (\%) & $5(3)$ & $3(3)$ & $2(4)$ \\
\hline \multicolumn{4}{|l|}{ Anti-CCP, No (\%) } \\
\hline Specificity (\%) & 98.8 & 98.1 & 100 \\
\hline Sensitivity (\%) & 75 & 50 & 100 \\
\hline PPV (\%) & 60 & 50 & 100 \\
\hline NPV (\%) & 99.4 & 98.1 & 100 \\
\hline \multicolumn{4}{|l|}{ RF } \\
\hline Specificity (\%) & 60.6 & 52.8 & 75.9 \\
\hline Sensitivity (\%) & 100 & 100 & 100 \\
\hline PPV (\%) & 6.0 & 3.8 & 13.3 \\
\hline NPV (\%) & 100 & 100 & 100 \\
\hline McNemar's test ( $p$ value) & $<0.0001$ & $<0.0001$ & $<0.0001$ \\
\hline$\kappa$ Value $(95 \% \mathrm{Cl})$ & $0.058(-0.013$ to 0.129$)$ & $0.021(-0.044$ to 0.086$)$ & $0.184(-0.041$ to 0.410$)$ \\
\hline
\end{tabular}

Figure 1 shows an overview of patients who have RA. Patients A and D have SS and RA, patients B and C have Sjögren's-like syndrome and RA while patients $\mathrm{E}$ and $\mathrm{F}$ do not have RA (RF was negative in both patients), but have a borderline anti-CCP. They could develop RA at a later stage. Patients A, B, and C have a positive anti-CCP.

In this study only four patients were diagnosed with RA. This limits the accuracy of the sensitivity, but is excellent for calculating the specificity. The rationale for this study is the fact that it is important to select only those patients with RA from a group in which most have a positive RF test, with the
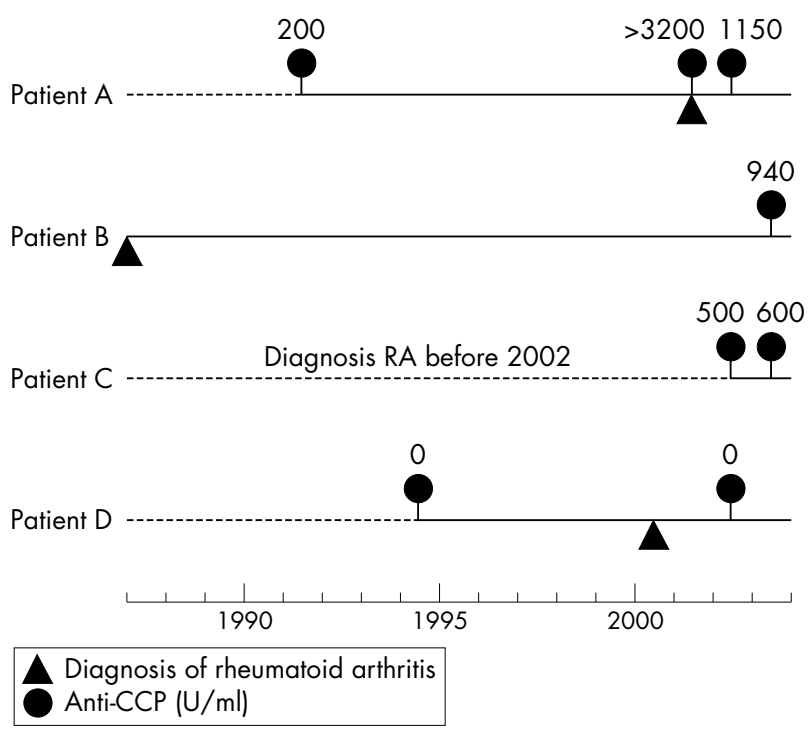

Figure 1 Timescale of the four patients with RA with the relevant antiCCP results. Patient A (SS) 1991 RF: $50 \mathrm{IU} / \mathrm{ml}, 2002$ RF: $200 \mathrm{IU} / \mathrm{ml}$; patient B (SS-like) 2003 RF: 1600 IU/ml; patient C (SS-like) 2002 RF: $50 \mathrm{IU} / \mathrm{ml}, 2003$ RF: $50 \mathrm{IU} / \mathrm{ml}$; patient D (SS) 1994 RF: $50 \mathrm{lU} / \mathrm{ml}, 2002$ RF: $12 \mathrm{IU} / \mathrm{ml}$. The evaluation criteria for anti-CCP are as follows: $\leqslant 25 \mathrm{U} / \mathrm{ml}$ are defined as negative, $>50 \mathrm{U} / \mathrm{ml}$ are positive. Samples with $>25 \mathrm{U} / \mathrm{ml}$ and $<50 \mathrm{U} / \mathrm{ml}$ were considered as borderline. The evaluation criteria for RF are as following: negative $(<12 \mathrm{lU} / \mathrm{ml})$ and positive ( $\geqslant 12 \mathrm{IU} / \mathrm{ml})$. help of a specific diagnostic test such as the anti-CCP test. When a cut off value of $100 \mathrm{U} / \mathrm{ml}$ for anti-CCP is used, the specificity of anti-CCP for RA is $100 \%$.

We conclude that the RF test for the diagnosis of RA in patients with SS has no value because about $40 \%$ of patients with SS have positive RF tests (94\% of these tests are false positive). The anti-CCP test, on the other hand, has a high specificity for RA.

\section{ACKNOWLEDGEMENTS}

We thank Jane Meijlink for her help with the English translation.

\section{Authors' affiliations}

C van Noord, H Hooijkaas, B C M Dufour-van den Goorbergh, P M van

Hagen, P L A van Daele, J P van de Merwe, Departments of Immunology and Internal Medicine, Erasmus MC, University Medical Centre Rotterdam, The Netherlands

Correspondence to: $\mathrm{Ms} C$ van Noord, Erasmus MC, University Medical Center Rotterdam, Department of Immunology, Dr Molewaterplein 50, 3015 GE Rotterdam, The Netherlands; charlottevannoord@hotmail.com

Accepted 22 August 2004

\section{REFERENCES}

1 Thomas E, Hay EM, Hajeer A, Silman AJ. Sjögren's syndrome: a communitybased study of prevalence and impact. Br J Rheumatol 1998;37:1069-76.

2 Schellekens GA, de Jong BA, van den Hoogen FH, van de Putte $L B$, van Venrooij WJ. Citrulline is an essential constituent of antigenic determinants recognized by rheumatoid arthritis-specific autoantibodies. J Clin Invest 1998;101:273-81.

3 Bas S, Perneger TV, Seitz M, Tiercy JM, Roux-Lombard P, Guerne PA. Diagnostic tests for rheumatoid arthritis: comparison of anti-cyclic citrullinated peptide antibodies, anti-keratin antibodies and $\lg M$ rheumatoid factors. Rheumatology (Oxford) 2002;41:809-14.

4 Newkirk MM. Rheumatoid factors: host resistance or autoimmunity? Clin Immunol 2002; 104: 1-13.

5 Schellekens GA, Visser $H$, de Jong BA, van den Hoogen FH, Hazes JM, Breedveld FC, et al. The diagnostic properties of rheumatoid arthritis antibodies recognizing a cyclic citrullinated peptide. Arthritis Rheum 2000;43:155-63

6 Bizzaro N, Mazzanti G, Tonutti E, Villalta D, Tozzoli R. Diagnostic accuracy of the anti-citrulline antibody assay for rheumatoid arthritis. Clin Chem 2001;47:1089-93.

7 van Venrooij WJ, Hazes JM, Visser $\mathrm{H}$. Anticitrullinated protein/peptide antibody and its role in the diagnosis and prognosis of early rheumatoid arthritis. Neth J Med 2002;60:383-8. 
8 Vitali C, Bombardieri S, Jonsson R, Moutsopoulos HM, Alexander EL, Carsons SE, et al. Classification criteria for Siögren's syndrome: a revised version of the European criteria proposed by the American-European Consensus Group. Ann Rheum Dis 2002:61:554-8.

9 Martin-Martin LS, Latini A, Pagano A, Ragno A, Stasi R, Coppe A, et al. A new mathematical model based on clinical and laboratory variables for the diagnosis of Siögren's syndrome. Clin Rheumatol 2003;22:123-6.

10 Arnett FC, Edworthy SM, Bloch DA, McShane DJ, Fries JF, Cooper NS, et al. The American Rheumatism Association 1987 revised criteria for the classification of rheumatoid arthritis. Arthritis Rheum 1988;31:315-24.

\section{Chemotherapeutic induced fascial oedema}

\section{Lim, R Kefford, N Manolios}

C hemotherapeutic agents have well recognised toxicities in addition to the usual features of nausea, vomiting, and myelosuppression. Toxicity affecting the skin and subcutaneous tissue is uncommon and poorly documented. Of the chemotherapeutic drugs, bleomycin is the best known for its ability to cause skin hyperpigmentation, Raynaud's phenomenon, and thickening of subcutaneous tissues resembling scleroderma, especially affecting the fingers. ${ }^{1}$ The taxanes, a class of antimicrotubule agents can cause macules, papules, plaques, and nail changes. Docetaxel, in particular, has been described as causing scleroderma-like changes.

The triazene derived compounds, dacarbazine and temozolomide, are chemotherapeutic agents similar to the nitrosoureas, which act as alkylating agents, predominantly through the methylation of the $\mathrm{O}^{6}$ position of guanine in DNA. Dacarbazine is an intravenous preparation with single agent activity against malignant melanoma with reported partial remission rates up to $20 \%$ and median response durations of 4-6 months. ${ }^{3}$ It is also active in Hodgkin's disease and soft tissue sarcomas. Temozolomide is an oral prodrug of 5-(3-methyltriazen-1-yl)-imidazole-4-carboxamide, the active metabolite of dacarbazine. Its major advantage is improved penetration into spaces, such as the central nervous system.

The dose limiting toxicity of both dacarbazine and temozolomide is myelosuppression. Nausea and vomiting occurs in up to $90 \%$ of patients. ${ }^{1}$ Skin toxicity is not described with either agent. In this case report, we describe the occurrence of fascial oedema and scleroderma-like skin changes with the use of these agents in the treatment of metastatic melanoma.

\section{CASE REPORT}

A 52 year old white woman presented with a 3 week history of "heaviness" of both thighs. She had also noted increasing tightness and swelling affecting both thighs, both shoulders, and the right side of her face and neck. There was no preceding history of Raynaud's phenomenon or musculoskeletal problems.

Four months earlier, she had been diagnosed with metastatic melanoma involving the liver and lung. Palliative chemotherapy with single agent dacarbazine was started (1700 mg infusion over 5 days every 3 weeks). There was a good response and the lung and liver metastases resolved. Four cycles of the dacarbazine chemotherapy were completed before the start of her lower limb symptoms. Other medical history consisted of hyperthyroidism treated with propylthiouracil, and a previous episode of idiopathic pancreatitis.

On examination, the skin was shiny and taut over the back of both thighs, extending over both buttocks. There was similar skin tightness over both shoulders, with less involvement of the right side of her face. No pitting was demonstrable. There were no peripheral stigmata of chronic sclerodermatous disease (telangiectasia, calcinosis, synovitis, sclerodactyly, or abnormal nailfold capillaries). The quadriceps and hamstring musculature were only mildly tender.

A full blood count and serum biochemistry, including creatine kinase, were normal. The patient was clinically and biochemically euthyroid. Erythrocyte sedimentation rate and $\mathrm{C}$ reactive protein were normal. She had a positive antinuclear antibody (speckled pattern with titre $1 / 160$, as well as nucleolar pattern with titre 1/640). Extractable nuclear antigens, double stranded DNA, and antineutrophil cytoplasmic antibodies were not detectable. Magnetic resonance imaging (using the STIR technique) of her lower limbs disclosed marked subcutaneous oedema with involvement of the fascia (fig 1). Open muscle biopsy of the right upper lateral thigh was unhelpful, with no evidence of inflammatory infiltration. The biopsy was unfortunately too superficial, with no fascia included. No malignant cells were seen in the biopsy sample and all cultures were negative.

A diagnosis of fascial oedema was made and the only change to her management was that dacarbazine chemotherapy was stopped. Over 2 weeks, the skin tightness and softening of subcutaneous tissues visibly reduced, with associated improvement in her symptoms.

Dacarbazine was again restarted, with five further cycles given, for the liver metastases. She then developed cerebral metastases, and dacarbazine was changed to temozolomide to enhance central nervous system penetration. After the first course of temozolamide at the usual dosage of $250 \mathrm{mg}$ on days $1-5$, she redeveloped the skin tightness in a similar distribution. Unfortunately, the patient soon developed a dense left hemiplegia. Chemotherapy was stopped and the patient admitted to a palliative hospital.

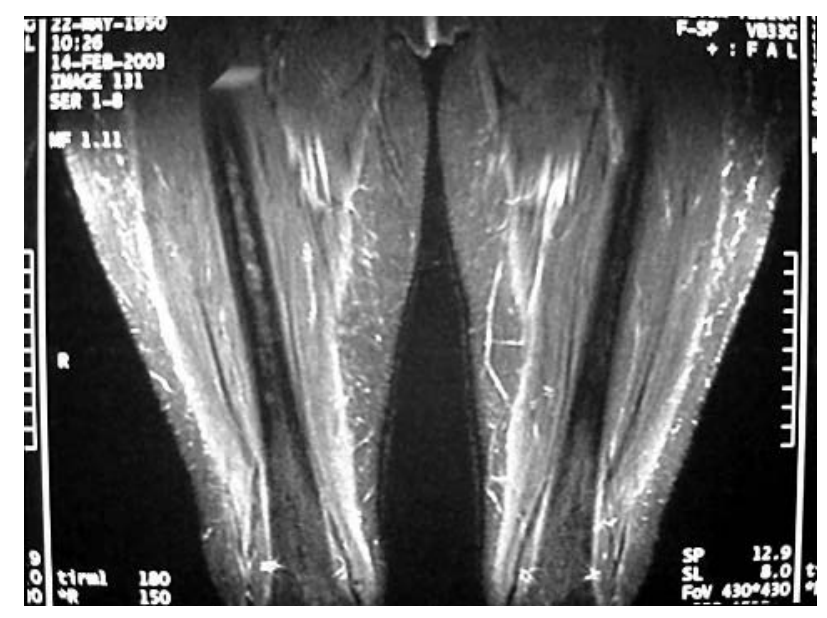

Figure 1 Magnetic resonance imaging (STIR technique) of thighs showing enhancement of the fascia. 


\section{DISCUSSION}

Fascial oedema is an uncommon condition of unknown cause that mimics scleroderma, with swelling, stiffness, reduced flexibility of limbs, and thickening of the subcutaneous tissue. Fascial oedema is not usually related to drug toxicity.

We report here the first case of diffuse fascial oedema with scleroderma-like skin changes in a female patient with metastatic melanoma being treated with dacarbazine and its analogue temozolamide. In this case a strong temporal relationship was found between the skin changes seen and drug use. Possible explanations of these skin changes include a direct drug effect; altered immune regulation secondary to drug or disease, leading to the development of autoantibodies and subsequent disease; paraneoplastic effect of melanoma; or coincidence. However, the improvement of clinical signs and symptoms followed by recurrence of these on rechallenge strongly favours a drug effect.
Authors' affiliations

I Lim, N Manolios, Department of Rheumatology, Westmead Hospital, Westmead, NSW, Australia 2145

R Kefford, Department of Oncology, Westmead Hospital, Westmead, NSW, Australia 2145

Correspondence to: A/Prof. N. Manolios, Department of

Rheumatology, Westmead Hospital, Westmead, NSW, Australia 2145; Nickm@westgate.wh.usyd.edu.au

Accepted 26 March 2004

\section{REFERENCES}

1 Souhami R, Tannock I, Hohenberger P, Horiot J-C. Oxford textbook of oncology, 2nd ed. Oxford: Oxford University Press, 2002.

2 Hassett G, Harnett P, Manolios N. Scleroderma in association with the use of docetaxel (Taxotere) for breast cancer. Clin Exp Rheumatol 2001;19:197-200.

3 DeVita V, Hellman S, Rosenberg S. Cancer: principles and practice of oncology, 6th ed. Lippincott: Williams \& Wilkins, 2001.

\section{Risk factors for accelerated atherosclerosis in patients with systemic lupus erythematosus}

\section{B Marasini, M De Monti, G Ghilardi}

A ccelerated atherosclerosis is a recognised leading cause of morbidity and mortality in systemic lupus erythematosus (SLE), ${ }^{1}$ and therefore the identification of patients with SLE at risk for cardiovascular (CV) events is important. However, the mechanisms of premature atherosclerosis associated with SLE are still unknown, with lupus itself a possible candidate and the role of traditional and nontraditional risk factors still uncertain. ${ }^{2-4}$ It has been recently suggested that mechanisms inherent to SLE might predispose the vascular wall to acceleration of the atherosclerotic process through traditional risk factors. ${ }^{5}$

\section{METHODS AND RESULTS}

We performed high resolution carotid ultrasonography in 48 consecutive patients (43 women, 5 men, aged 19-77 years) fulfilling the American Rheumatism Association criteria for SLE, ${ }^{6}$ without clinical evidence of overt atherosclerosis or diabetes. Plaque at carotid bifurcation was found in $6 / 48$ (13\%) and abnormal intimal medial thickness (IMT, considered "abnormal" if $>0.7 \mathrm{~mm}$ ) in $8 / 48(17 \%)$ patients.

Older age and high blood pressure were confirmed to be strongly associated with carotid lesions. Patients with plaque or abnormal IMT were significantly older (mean (SD) 69 (7) $v$ 39 (12) years or 62 (14) v 39 (14) years, $\mathrm{p}<0.0001$ and $\mathrm{p}=0.0014$, respectively) and higher blood pressure $(>140 /$ $90 \mathrm{~mm} \mathrm{Hg}$ or treatment with antihypertensive drugs) was also more common in plaque positive $(67 \%)$ than in plaque negative $(7 \%)$ patients $(\mathrm{p}=0.0001)$.

Moreover, among traditional risk factors, we found that men with SLE tended to have plaque more often $(20 \%)$ than women with SLE (12\%), in accord with recent observations both on patients with SLE and the general population. ${ }^{4}$

We did not find any relationship between carotid abnormalities, cumulative prednisone intake, or inflammation markers (erythrocyte sedimentation rate, fibrinogen, and $\mathrm{C}$ reactive protein). As recently pointed out, ${ }^{2}$ inflammation markers, which fluctuate as a consequence of disease activity and treatment, cannot serve as suitable risk markers in SLE, even if increasing evidence indicates that atherosclerosis is an inflammatory disease.
An intriguing finding of our study was the negative association between carotid abnormalities and antinuclear antibodies (ANA). Plaque was more common in ANA negative patients (40\%) than in ANA positive patients (9\%) $(\mathrm{p}=0.0495)$. Our observation may be consistent with the recent study of Roman et al, ${ }^{3}$ who found that anti-Sm and anti-RNP autoantibodies were less common in patients with plaque, and none of the six Sm positive patients of our series had plaque. Interestingly, it has been recently suggested that $\mathrm{Sm}$ antibodies exert a protective effect against coronary artery calcification in SLE. ${ }^{8}$

\section{DISCUSSION}

Although the role of autoantibodies in atherosclerosis, ${ }^{9}$ and particularly in accelerated atherosclerosis of SLE, is still a matter of debate, ${ }^{30}$ the proposed existence of two clinical patterns of SLE, one at higher risk of CV events, characterised by limited autoantibody production, and the other at lower risk but with a wider autoantibody spectrum, ${ }^{3}$ opens a new promising research agenda.

Because in atherosclerosis there is evidence for an involvement of humoral immunity, an inappropriate autoimmune response inherent to the process of SLE might have a role in chronic plaque development. On the other hand, aggressive immunosuppressant drugs for more severe diseases might lower or even suppress autoantibody production. Moreover, a genetic predisposition linked to autoantibody repertoires and to clinical subsets of disease cannot be ruled out.

More studies are needed to assess whether ANA testing might represent an additional tool for identifying patients with SLE at risk for CV events.

\section{Authors' affiliations}

B Marasini, M De Monti, G Ghilardi, Department of Medicine, Surgery and Dentistry, S Paolo Hospital, University of Milan, Italy

Correspondence to: Professor B Marasini; bianca.marasini@unimi.it

Accepted 6 May 2004 


\section{REFERENCES}

1 Bruce IN, Gladman DD, Urowitz MB. Systemic lupus erythematosus: premature atherosclerosis in systemic lupus erythematosus. Rheum Dis Clin North Am 2000;26:257-78.

2 Doria A, Shoenfeld Y, Wu R, Gambari PF, Puato M, Ghirardello A, et al. Risk factors for subclinical atherosclerosis in a prospective cohort of patients with systemic lupus erythematosus. Ann Rheum Dis 2003;62:1071-7.

3 Roman MJ, Shanker B-E, Davis A, Lockshin MD, Sammaritano L, Simantov R, et al. Prevalence and correlates of accelerated atherosclerosis in systemic lupus erythematosus. N Engl J Med 2003;349:2399-406.

4 Anasuma Y, Oeser A, Shintani AK, Turner E, Olsen N, Fazio S, et al. Premature coronary-artery atherosclerosis in systemic lupus erythematosus. N Engl J Med 2003;349:2407-15.

5 Selzer F, Sutton-Tyrrell K, Fitzgerald SG, Pratt JE, Tracy RP, Kuller LH, et al. Comparison of risk factors for vascular disease in the carotid artery and aorta in women with systemic lupus erythematosus. Arthritis Rheum 2004;50:151-9.

6 Tan EM, Cohen AS Fries JF, Masi AT, McShane DJ, Rothfield NF, et al. The 1982 revised criteria for the classification of systemic lupus erythematosus. Arthritis Rheum 1982;25:1271-7.

7 lemolo F, Martiniuk A, Steinman DA, Spence JD. Sex differences in carotid plaque and stenosis. Stroke 2004;35:477-81.

8 Manger K, Kusus M, Forster C, Ropers D, Daniel WG, Kalden JR, et al. Factors associated with coronary artery calcification in young female patients with SLE. Ann Rheum Dis 2003;62:846-50.

9 Brusca I, Sarullo FM, Fazio M. Presence of antinuclear antibodies and coronary heart disease. Ann Rheum Dis 2002;61:1038.

10 Grainger DJ, Bethell HWL. High titres of serum antinuclear antibodies, mostly directed against nucleolar antigens, are associated with the presence of coronary atherosclerosis. Ann Rheum Dis 2002;61: 110-14.

\section{Angiotensin converting enzyme (ACE) gene polymorphisms and lupus disease severity: a promising link}

\section{Saeed, S F Mekan, M A Rabbani, F M Arain, M Arif, S Shaharyar}

$\mathrm{T}$ he ACE insertion/deletion (I/D) polymorphism has been inconsistently reported to be associated with systemic lupus erythematosus (SLE). ${ }^{1-3}$ We proposed the hypothesis that the genetic sequence variation of ACE may not cause SLE, but may participate in disease progression. Among the 13 polymorphisms of the ACE gene recently reported, a polymorphism in exon 17, ACE $2350 \mathrm{G}>\mathrm{A}$, has the most significant effect on plasma ACE concentrations ${ }^{4}$ and has been shown to be associated with essential hypertension. ${ }^{5}$ We carried out a retrospective, case-control study of the two polymorphisms for putative associations with SLE and allied phenotypes among a homogeneous Asian population.

\section{METHODS AND RESULTS}

We investigated a sample group of 39 patients with SLE (mean (SD) age 33 (10) years; nine men) and 79 healthy control Pakistani subjects from the Aga Khan University Hospital, Karachi, matched for age (35 (9) years) and sex (20 men). Informed consent was taken from all participants and international guidelines for sample collection were followed. ${ }^{6}$ All patients fulfilled the American College of Rheumatology criteria for SLE. ${ }^{7}$ We used the Systemic Lupus Activity Measure $(\text { SLAM })^{8}$ score at diagnosis as an indicator of disease severity; a SLAM score $\geqslant 20$ indicating severe SLE and $\leqslant 10$, mild disease. Our patients predominantly had moderate disease activity (SLAM 11-19) at diagnosis and only three patients had mild SLE.

Genotyping for ACE I/D and $2350 \mathrm{G}>\mathrm{A}$ polymorphisms was done as previously described. ${ }^{5}{ }^{6}$ Table 1 shows that the differences in the distributions of the six genotypes were not significant for either of the ACE polymorphisms, as assessed by $\chi^{2}$ analyses on $3 \times 2$ tables. The groups were in HardyWeinberg equilibrium for both markers as shown by the $\mathrm{D}_{\mathrm{A}}$ statistics. ${ }^{9}$ The frequency of the $2350 \mathrm{~A}$ allele increased from $17 \%$ in mild SLE to $28 \%$ in moderate disease to $32 \%$ in severe SLE.

Haplotype analysis and linkage disequilibrium (LD) statistics obtained using Powermarker version $2.0^{10}$ showed that the $\mathrm{D}$ and $2350 \mathrm{~A}$ alleles were in strong linkage disequilibrium (LD) $\left(\mathrm{D}=-0.23, \mathrm{D}^{\prime}=0.72, \chi^{2}=64.4, \mathrm{p}<0.001\right)$. The extent of LD was more in severe SLE $\left(\mathrm{D}^{\prime}=-0.52, \chi^{2}=5.04\right.$, $\mathrm{p}=0.025)$ than in mild to moderate disease $\left(\mathrm{D}^{\prime}=-0.26\right.$, $\left.\chi^{2}=1.42, p=0.23\right)$. The DA haplotype was more frequent in severe SLE than in mild to moderate disease (odds ratio $=1.43,95 \%$ confidence interval $=0.38$ to 5.35, $\left.\chi^{2}=0.36,1 \mathrm{df}, \mathrm{p}=0.55\right)$.

\section{DISCUSSION}

SLE is present in an aggressive form (moderate to severe disease) in the Pakistani population. Although assessing SLE severity is not simple, as various factors such as response to treatment and type of organ affected and organ damage determine the nature of the disease, we used the SLAM index at diagnosis as an indicator of disease severity. All our patients presented within 6 months of symptom onset, which made SLAM at diagnosis a comparable index of SLE severity.

The ACE gene does not appear play a part in the development of SLE as shown by the lack of association of

Table 1 Distribution of ACE $2350 \mathrm{G}>\mathrm{A}$ and I/D genotypes and allele frequencies (standard errors) as well as $D_{A}$ statistics in the patients with SLE and controls

\begin{tabular}{|c|c|c|c|c|}
\hline SNP & $\begin{array}{l}\text { Genotypes/ } \\
\text { alleles }\end{array}$ & $\begin{array}{l}\text { Patients with SLE } \\
(\mathrm{n}=39)\end{array}$ & $\begin{array}{l}\text { Controls } \\
(n=79)\end{array}$ & $\begin{array}{l}\text { Association } \\
\left(\chi^{2}(2 d f) / p\right)\end{array}$ \\
\hline $\begin{array}{l}\text { ACE I/D } \\
D_{A} / \chi^{2}\end{array}$ & $\begin{array}{l}\text { II/ID/DD } \\
\text { I/D }\end{array}$ & $\begin{array}{l}14 / 14 / 11 \\
0.54(0.04) / 0.46(0.04) \\
0.07 / 3.14\end{array}$ & $\begin{array}{l}27 / 38 / 14 \\
0.58(0.06) / 0.42(0.06) \\
0.0008 /<0.001\end{array}$ & $2.26 / 0.32$ \\
\hline $\begin{array}{l}\text { ACE } 2350 \mathrm{G}>\mathrm{A} \\
\mathrm{D}_{\mathrm{A} / \chi^{2}}\end{array}$ & $\begin{array}{l}\text { GG/GA/AA } \\
\text { G/A }\end{array}$ & $\begin{array}{l}18 / 20 / 1 \\
0.72(0.07) / 0.29(0.07) \\
-0.059 / 3.06\end{array}$ & $\begin{array}{l}38 / 35 / 6 \\
0.70(0.04) / 0.30(0.04) \\
-0.014 / 0.354\end{array}$ & $1.41 / 0.49$ \\
\hline
\end{tabular}


the ACE I/D and G>A polymorphisms, which is consistent with previous findings for ACE I/D. ${ }^{2}$ Though the frequency of the 2350A allele was similar in both groups, its distribution was skewed towards severe SLE (SLAM >20). The D and the $2350 \mathrm{~A}$ alleles were in strong LD and the predominant transmission of the DA haplotype in severe SLE indicated its association with severe SLE. These results support the involvement of ACE polymorphisms with increasing disease severity of SLE.

\section{ACKNOWLEDGEMENTS}

We are grateful to our patients for their participation and to Drs Philippe Frossard, Ata Khan, and Adil Abbas for help with patient recruitment.

\author{
Authors' affiliations \\ M Saeed, S F Mekan, F M Arain, M Arif, S Shaharyar, Department of \\ Biological and Biomedical Sciences, The Aga Khan University, Karachi, \\ Pakistan \\ M A Rabbani, Department of Medicine, The Aga Khan University, \\ Karachi, Pakistan \\ Correspondence to: DrM Saeed, Department of Biological and \\ Biomedical Sciences, The Aga Khan University, Stadium Road, Karachi, \\ 74800, Pakistan; drsaeed2k @yahoo.com \\ Accepted 23 May 2004
}

\section{REFERENCES}

1 Parsa A, Peden E, Lum RF, Seligman VA, Olson JL, Li H, et al. Association of angiotensin-converting enzyme polymorphisms with systemic lupus erythematosus and nephritis: analysis of 644 families. Genes Immunity 2002;3(suppl 1):S42-6

2 Kaufman KM, Kelly J, Gray-McGuire C, Asundi N, Yu H, Reid J, et al. Linkage analysis of angiotensin-converting enzyme (ACE) insertion/deletion polymorphism and systemic lupus erythematosus. Mol Cell Endocrinol 2001;177:81-5.

3 Akai $Y$, Sato H, Iwano M, Kurumatani N, Kurioka H, Kubo A, et al. Association of an insertion polymorphism of angiotensin-converting enzyme gene with the activity of lupus nephritis. Clin Nephrol 1999:51:141-6.

4 Zhu X, Bouzekri N, Southam L, Cooper RS, Adeyemo A, McKenzie CA, et al. Linkage and association analysis of angiotensin l-converting enzyme (ACE)gene polymorphisms with ACE concentration and blood pressure. Am J Hum Genet 2001;68:1139-48.

5 Saeed Mahmood M, Saboohi K, Osman Ali S, Bokhari AM, Frossard PM. Association of the angiotensin-converting enzyme (ACE) gene G2350A dimorphism with essential hypertension. J Hum Hypertens 2003;17:719-23.

6 Gostin LO. National health information privacy: regulations under the Health Insurance Portability and Accountability Act. JAMA 2001;285:3015-21.

7 Hochberg MC. Updating the American College of Rheumatology revised criteria for the classification of systemic lupus erythematosus [abstract]. Arthritis Rheum 1997;40(suppl 9):1725.

8 Gladman DD Goldsmith CH, Urowitz MB, Bacon P, Bombardier C, Isenberg D, et al. Crosscultural validation and reliability of 3 disease activity indices in systemic lupus erythematosus. J Rheumatol 1992;19:608-11.

9 Haviland MB, Kassling AM, Davingnon J, Sing CF. Estimation of HardyWeinberg pairwise disequilibrium in apolipoprotein AI-CIII-AIV gene cluster. Am J Hum Genet 1991;49:350-65.

10 Lui J. Powermarker version 2.0 beta. www.powermarker.net (accessed 11 October 2004). Copyright 2001-2003.

\title{
Rheumatoid arthritis in Poland and Lithuania: different clinical course and HLA associations despite similar genetic background
}

\author{
R Płoski, I Butrimiene, E Kamińska, K Valiukiene, P Sliwińska, E Kubasiewicz, A Kozakiewicz, \\ A Smerdel, V Kučinskas, J Jaworski, E Jastrzębska, O Forre, A Venalis, J Pazdur
}

A recognised feature of rheumatoid arthritis (RA) is its clinical heterogeneity, which may be caused by HLA factors. This theory is supported by observations that relatively severe and mild RA are associated with, respectively, $\mathrm{DRBl}^{*} 04^{1}$ and $\mathrm{DRBl}^{*} 01 .^{2-4}$ Further, comparisons between populations show that the disease course in the Mediterranean is milder than in northern Europe, ${ }^{5-8}$ correlating with a higher frequency of $\mathrm{DRB} 1^{*} 01$ and lower frequency of $\mathrm{DRBI}^{*} 04$ in the former than in the latter region. ${ }^{679}$

\section{METHODS AND RESULTS}

Poland and Lithuania are neighbouring central European countries. During clinical practice we noted that RA was less severe in Lithuanian than in Polish patients. To test this observation we prospectively analysed 24 Polish and 20 Lithuanian randomly recruited patients with recent onset RA diagnosed by modified American Rheumatism Association criteria. The patients had a similar mean (SD) age (53.6 (11.4) $v 57.0$ (14.2) years), mean (SD) age of RA onset (52.2 (11.2) v 55.8 (14.4) years), mean (SD) disease duration (16.9 (13.6) v 13.9 (9.8) months), rheumatoid factor (RF) seropositivity $(50 \% \vee 40 \%)$, and mean (SD) Steinbrocker stage ( $1.5(0.5) \vee 1.5(0.5))$, respectively for Polish and Lithuanian cohorts. The only significant difference was higher frequency of women with RA among the Polish group (22/24 (92\%) $v$ $10 / 20(50 \%), p<0.01)$.
The first assessment of the patients was performed before the start of treatment and then after 2 months and after 1 year. The analysis at baseline indicated significantly more severe disease among Polish than Lithuanian patients (table 1). After 2 months, probably as a result of treatment which was more aggressive in the Poles, disease activity in both groups decreased and most differences present at baseline were no longer seen (table 1). The clinical and laboratory results were similar also after 1 year (table 1 ), but radiographic analysis performed at that time showed an increase in mean (SD) erosion score and Larsen score in Poles (respectively, 0.7 (1.3) and 4.0 (6.5)), but not in Lithuanians. The difference in Larsen score progression between the two cohorts was significant $(\mathrm{p}<0.05, t$ test $)$.

Because of the relative excess of men among the Lithuanian patients we also performed analysis after adjusting for the sex of the patients. We found that all the differences seen between the cohorts at baseline on univariate analysis (table 1) were also present in the multivariate analysis controlling for sex (not shown).

The participants of the study and some additional patients (in total 49 Poles and 32 Lithuanians) were genomically typed for DRBI* 01 and DRBI ${ }^{*} 04$, and 158 Poles $^{10}$ and 134 Lithuanians fully typed for DRBI (low resolution) constituted ethnically matched controls. When patients were compared with their respective controls a significant increase 
Table 1 Measures of disease severity at baseline and follow up of the patients

\begin{tabular}{|c|c|c|c|c|c|c|c|c|c|c|c|c|}
\hline \multirow[b]{3}{*}{ Characteristic } & \multicolumn{4}{|c|}{ Baseline } & \multicolumn{4}{|c|}{ After 2 months } & \multicolumn{4}{|c|}{ After 12 months } \\
\hline & \multicolumn{2}{|l|}{$\begin{array}{l}\text { Poland } \\
(n=24)\end{array}$} & \multicolumn{2}{|c|}{$\begin{array}{l}\text { Lithuania } \\
(n=20)\end{array}$} & \multicolumn{2}{|c|}{$\begin{array}{l}\text { Poland } \\
(n=24)\end{array}$} & \multicolumn{2}{|c|}{$\begin{array}{l}\text { Lithuania } \\
(n=16)\end{array}$} & \multicolumn{2}{|c|}{$\begin{array}{l}\text { Poland } \\
(n=24)\end{array}$} & \multicolumn{2}{|c|}{$\begin{array}{l}\text { Lithuania } \\
(n=12)\end{array}$} \\
\hline & Mean & SD & Mean & SD & Mean & SD & Mean & SD & Mean & SD & Mean & SD \\
\hline Morning stiffness (min) & 126.7 & $67.2^{1}$ & 106.1 & $97.9^{11}$ & 71.3 & 68.8 & 51.9 & 38.9 & 54.0 & 56.8 & 31.7 & 36.8 \\
\hline Number of tender joints & 12.1 & $4.3^{2}$ & 11.3 & $3.2^{12}$ & 6.3 & 4.6 & 8.7 & 3.0 & 4.7 & 4.0 & 5.4 & 3.8 \\
\hline Number of swollen joints & 7.8 & $3.3^{3}$ & 4.6 & $2.9^{13}$ & 3.8 & 3.5 & 3.0 & 1.5 & 2.9 & 2.7 & 2.5 & 1.8 \\
\hline VAS & 7.2 & $1.7^{4}$ & 5.1 & 2.0 & 3.6 & 2.3 & 4.1 & 1.8 & 3.1 & 2.0 & 3.0 & 1.2 \\
\hline Ritchie index & 21.7 & $8.6^{5}$ & 16.9 & $6.8^{14}$ & 10.0 & 8.6 & 10.0 & 4.5 & 7.5 & 7.4 & 5.8 & 4.0 \\
\hline DAS28 & 5.8 & $0.7^{6}$ & 5.0 & $0.4^{15}$ & 4.3 & 1.2 & 4.4 & $0.5^{18}$ & 3.6 & 1.2 & 3.8 & 0.7 \\
\hline Haemoglobin (g/l) & 105 & $16^{7}$ & 123 & 15 & 110 & 14 & 123 & $14^{19}$ & 115 & 18 & 121 & 40 \\
\hline $\operatorname{ESR}(\mathrm{mm} / 1 \mathrm{st} h)$ & 81.6 & $29.1^{8}$ & 39.2 & $12.3^{16}$ & 45.1 & $34.7^{17}$ & 27.9 & 16.4 & 27.7 & 18.9 & 23.1 & 10.9 \\
\hline Erosion score & 4.2 & $5.3^{9}$ & 0.2 & 0.5 & ND & ND & ND & ND & 4.9 & $5.3^{20}$ & 0.3 & 0.6 \\
\hline Larsen score & 33.9 & $17.9^{10}$ & 18.1 & 5.3 & ND & ND & ND & ND & 37.9 & $17.5^{21}$ & 18.3 & 4.7 \\
\hline \multicolumn{13}{|c|}{ 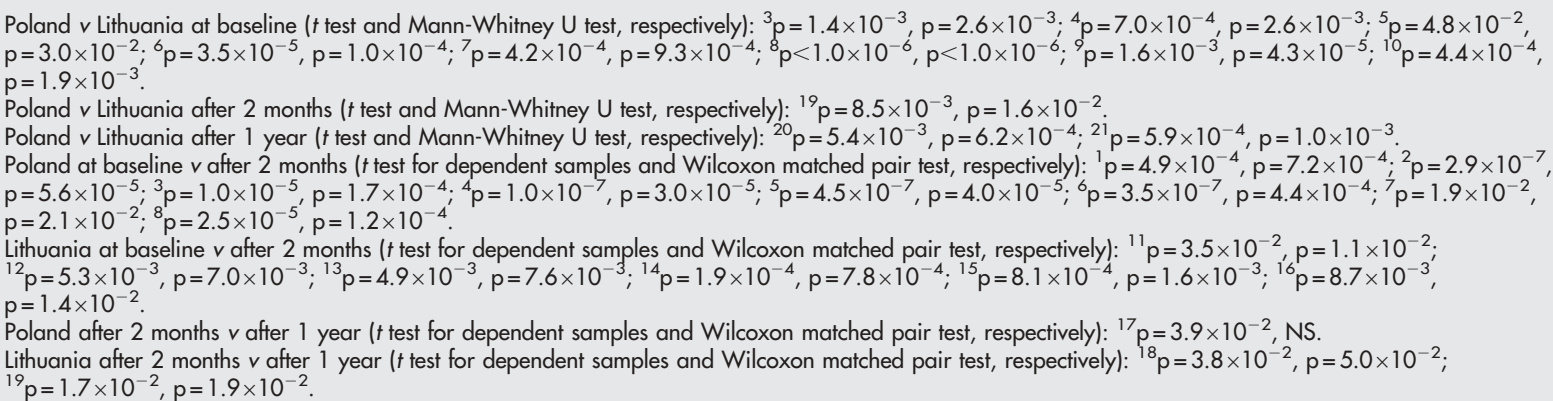 } \\
\hline
\end{tabular}

of $\mathrm{DRBI}^{*} 04(41 \% \vee 19 \%$, odds ratio $(\mathrm{OR})=2.9, \mathrm{p}<0.002)$ but not DRB1*01 (6\% $v 17 \%$, NS) was found in the Polish group, whereas among the Lithuanians there was an increase of $\mathrm{DRB1}^{*} 01 \quad(47 \% \vee 21 \%, \mathrm{OR}=3.3, \mathrm{p}<0.003)$ but not of $\mathrm{DRBI}^{*} 04(22 \% v 15 \%$, NS). The increase of DRBI*01 among the Lithuanian patients was significant also when compared with the Polish patients $(\mathrm{p}<0.00005)$. No statistically significant differences in the frequencies of any of the HLA $^{*}$ DRBl alleles were found between Polish and Lithuanian controls (not shown).

\section{DISCUSSION}

The presented data are interesting in the context of studies of RA features in southern $v$ northern Europe. ${ }^{679}$ Although the association of mild (among Lithuanians) and severe disease (among Poles) with, respectively, DRB ${ }^{*} 01$ and DRB1*04 was consistent with these reports, ${ }^{679}$ the lack of difference in distribution of HLA-DRBl alleles among controls from both populations does not support the hypothesis that variation in population frequency of $\mathrm{DRBI}^{*} 01$ and $\mathrm{DRBI}{ }^{*} 04$ is a general determinant of geographical differences in RA severity. ${ }^{69}$

\section{Authors' affiliations}

R Płoski, E Jastrzębska, Human Molecular Genetics Laboratory, Department of Forensic Medicine and Department of Paediatric Diabetes and Birth Defects, Medical University, Warsaw, Poland

I Butrimiene, K Valiukiene, A Venalis, Vilnius University, Institute of Experimental and Clinical Medicine, Vilnius, Lithuania

E Kamińska, P Sliwińska, E Kubasiewicz, A Kozakiewicz, J Jaworski, J Pazdur, Institute of Rheumatology, Warsaw, Poland

A Smerdel, O Forre, Institute of Immunology and Centre for Rheumatic Diseases, Rikshospitalet University Hospital, Oslo, Norway V Kučinskas, Department of Human and Medical Genetics, Vilnius University, Vilnius, Lithuania
Correspondence to: Dr R Płoski, Human Molecular Genetics Laboratory, Department of Forensic Medicine and Department of Paediatric Diabetes and Birth Defects, Medical University, Warsaw, ul Oczki 1, 02-007 Warsaw, Poland; rploski@wp.pl

Accepted 26 March 2004

\section{REFERENCES}

1 Weyand CM, Hicok KC, Conn DL, Goronzy JJ. The influence of HLA-DRB 1 genes on disease severity in rheumatoid arthritis. Ann Intern Med 1992; 117:801-6.

2 Bardin T, Legrand L, Naveau B, Marcelli-Barge A, Debeyre N, Lathrop GM, et al. HLA antigens and seronegative rheumatoid arthritis. Ann Rheum Dis 1985;44:50-3.

3 Singal DP, Green D, Reid B, Gladman DD, Buchanan WW. HLA-D region genes and rheumatoid arthritis (RA): importance of $D R$ and $D Q$ genes in conferring susceptibility to RA. Ann Rheum Dis 1992;51:23-8.

4 Ploski R, Mellbye OJ, Ronningen KS, Forre O, Thorsby E. Seronegative and weakly seropositive rheumatoid arthritis differ from clearly seropositive rheumatoid arthritis in HLA class II associations. J Rheumatol 1994;21:1397-402.

5 Abdel-Nasser AM, Rasker JJ, Valkenburg HA. Epidemiological and clinical aspects relating to the variability of rheumatoid arthritis. Semin Arthritis Rheum 1997;27:123-40.

6 Drosos AA, Lanchbury JS, Panayi GS, Moutsopoulos HM. Rheumatoid arthritis in Greek and British patients. A comparative clinical, radiologic, and serologic study. Arthritis Rheum 1992;35:745-8.

7 Ronda E, Ruiz MT, Pascual E, Gibson T. Differences between Spanish and British patients in the severity of rheumatoid arthritis: comment on the article by Drosos et al. Arthritis Rheum 1994:37:147-8.

8 Carmona L, Gonzalez-Alvaro I, Balsa A, Angel BM, Tena X, Sanmarti R. Rheumatoid arthritis in Spain: occurrence of extra-articular manifestations and estimates of disease severity. Ann Rheum Dis 2003;62:897-900.

9 Balsa A, Minaur NJ, Pascual-Salcedo D, McCabe C, Balas A, Fiddament B, et al. Class II MHC antigens in early rheumatoid arthritis in Bath (UK) and Madrid (Spain). Rheumatology (Oxford) 2000;39:844-9.

10 Ploski R, Ronningen KS, Thorsby E. HLA class II profile of a Polish population: frequencies of DRB1, DQA1, DQB1, and DPB1 alleles and DRB1-DQA1DQB1 haplotypes. Transplant Proc 1996;28:3431-2. 


\title{
Lambert-Eaton myasthenic syndrome and undifferentiated connective tissue disease in a patient carrying the 8.1 ancestral haplotype
}

\author{
M A Kriegel, J R Kalden, H M Lorenz
}

Ann Rheum Dis 2005;64:167-168. doi: 10.1136/ard.2004.021436

A 49 year old woman with polyneuropathy, glomerulonephritis, leucocytoclastic vasculitis, restrictive lung disease, scleroderma-like skin changes, and myalgia, developed progressive myopathy, autoantibodies against voltage gated calcium channels (VGCCs) and a typical electromyographic pattern in accordance with a LambertEaton myasthenic syndrome (LEMS). HLA typing showed that the patient carried the 8.1 ancestral haplotype (HLA-Al, B8, DR3), associated with multiple immunological diseases. ${ }^{1}$ To our knowledge, this is the first presentation of LEMS occurring in a patient with undifferentiated connective tissue disease.

\section{CASE REPORT}

Our patient initially presented at the age of 32 (in 1987) with sicca syndrome and Raynaud's phenomenon followed by arthralgia, malaise, and paraesthesia. She subsequently developed leucocytoclastic vasculitis, restrictive lung disease, scleroderma-like skin changes, and proteinuria responsive to steroids. Rheumatoid factor was occasionally positive, while C4 was persistently low to undetectable. SSB and anti-Sm antibodies were once weakly positive (but never thereafter), while low titres of antinuclear antibodies, IgM and IgG immune complexes were increased on several visits. SSA, dsDNA, UIRNP, phospholipid, cANCA, pANCA, Jo-1, and centromere antibodies were negative on several occasions. Thus, her clinical and laboratory investigations did not allow a definite diagnosis at this point.

Starting in 1996-97, the patient noticed slowly progressive loss of strength in the lower extremities (predominantly thighs), rendering her incapable of walking long distances at times. In addition, she had a vasculitic flare, which was eventually controlled with azathioprine. The myopathy, however, persisted for the following years with tolerable symptoms. Various immunosuppressive agents (including methotrexate and ciclosporin A) required for treatment of a progressive polyneuropathy due to epineural vasculitis also did not alter the course of the myopathy. Serum creatine kinase was never raised and multiple clinical and laboratory investigations did not point towards infectious, autoimmune, metabolic, or endocrine causes. In addition, Sjögren's syndrome associated with the vasculitis was diagnosed in the same year, explaining several, but not all, of her rheumatological symptoms.

In 1999, muscle weakness progressed to the upper extremities, while loss of strength, especially in both hip flexors and extensors, increased significantly (up to paresis grade $2 / 5$ for flexors). A muscle biopsy ( $M$ deltoideus) performed 1 year later excluded any inflammatory infiltrates. Steroid induced myopathy was clinically suspected. Stopping the steroid treatment, however, did not relieve the myopathic symptoms. Further, the patient developed fever of unknown origin in 2001 and received netilmicin as part of the antibiotic coverage. This antibiotic (from the class of aminoglycosides known to exacerbate LEMS ${ }^{2}$ ) was associated with a dramatic deterioration of her muscle weakness in the lower extremities (especially hip flexors and extensors, but also knee flexors). Electromyographic studies finally showed a pathological increment after stimulation suggestive of LEMS. Positive autoantibodies against VGCCs confirmed the diagnosis, and daily treatment with 3,4-diaminopyridine improved all myasthenic symptoms after the first dose. Extended tumour screening remains negative to date.

In 2002 the patient surprisingly developed symmetric myalgias of the upper extremities not responsive to 3,4diaminopyridine. These distinctive muscular symptoms evolved after a gastrointestinal infection. Creatine kinase was still in the normal range, but the erythrocyte sedimentation rate was significantly raised. A high dose of steroids promptly relieved these symptoms, suggesting another, possibly vasculitic, cause for her sequelae at this time.

Finally, recent investigations showed a typical HLA pattern associated with multiple autoimmune diseases (HLA-Al, B8, DR3; table 1$)^{1}$ and increased basal tumour necrosis factor $\alpha$ $(\mathrm{TNF} \alpha)$ levels $(10.8 \mathrm{pg} / \mathrm{ml}$; normal range $0.1-8.1 \mathrm{pg} / \mathrm{ml})$. Interestingly, raised serum TNF $\alpha$ was measurable, although the patient's blood was drawn after several weeks of inactive disease defined by lack of signs, symptoms, or laboratory data suggestive of a flare. The patient's only immunosuppressive drug at this time was azathioprine and tapering doses of steroids.

\section{DISCUSSION}

LEMS is a rare autoimmune disorder of the neuromuscular junction characterised by autoantibodies against VGCCs. ${ }^{2}$ Cancer is frequently associated and usually detected within 2 years after diagnosis. ${ }^{2}$ Our patient, however, is a 49 year old, female non-smoker with coexisting systemic autoimmune disease. In addition, HLA-DRB*0301, DQB1*0201, and HLA-B8 are strongly associated with non-neoplastic LEMS, arguing against paraneoplasic mechanisms. ${ }^{34}$

LEMS has been reported in association with only a few systemic autoimmune diseases. ${ }^{5-7}$ Here we described a patient

Table 1 Comparison of the ancestral haplotype AH 8.1 with our patient's HLA alleles*

\begin{tabular}{|c|c|c|}
\hline & AH 8.1 & Patient \\
\hline Class I & $\begin{array}{l}\text { HLA-A1 } \\
\text { HLA-Cw7 } \\
\text { HLA-B8 }\end{array}$ & $\begin{array}{l}\text { HLA-A1; HLA-A2 } \\
\text { ND } \\
\text { HLA-B7; HLA-B8 }\end{array}$ \\
\hline Central MHC & $\begin{array}{l}\text { TNF AB*a2b3; TNF N*S } \\
C 2^{*} C \\
B f^{*} S \\
C 4 A^{*} Q 0 ; C 4 B^{*} B 1\end{array}$ & $\begin{array}{l}\text { ND } \\
\text { ND } \\
\text { ND } \\
\text { ND }\end{array}$ \\
\hline Class II & $\begin{array}{l}\text { HLA-DRB } 1{ }^{*} 0301 \\
\text { HLA-DRB3*0101 } \\
\text { HLA-DQA } 1^{*} 0501 \\
\text { HLA-DQB } 1{ }^{*} 0201\end{array}$ & $\begin{array}{l}\text { HLA-DRB } 1{ }^{*} 0301 \\
\text { HLA-DRB } 3 * 01 \\
\text { HLA-DQB } 1 * 0502 \\
\text { HLA-DQB } 1{ }^{* 0201}\end{array}$ \\
\hline
\end{tabular}


with undifferentiated connective tissue disease ${ }^{8}$ and Sjögren's syndrome before the development of LEMS. The diversity of autoimmune phenomena, including the recent onset of LEMS, prompted us to investigate the patient's HLA typing. In addition to the notion that this LEMS might be non-neoplastic, ${ }^{3}{ }^{4}$ the distinct combination of her HLA alleles indicated the presence of an ancestral haplotype (table 1) which has been associated with various autoimmune conditions. ${ }^{1}$ Although polymorphisms in HLA molecules are likely to be involved in predisposition to autoimmunity, the striking association of this haplotype might also be partly explained by linkage of disease promoting genes within the central major histocompatibility complex (MHC) region. Of note, a genetically determined high setting of TNF $\alpha$ has been associated with this haplotype. ${ }^{9}$ Raised levels of TNF $\alpha$ have also been linked to LEMS. ${ }^{10}$ Our patient indeed showed increased serum levels of TNF $\alpha$ despite inactive disease. Thus, this central cytokine might possibly play a part in the pathogenesis of at least some of the various autoimmune phenomena seen in our patient.

In summary, this report further strengthens the link between autoimmunity to connective tissue and the nervous system, together with a common genetic susceptibility region. It also demonstrates the difficulties of differentiating muscle weakness in patients with systemic autoimmunity.

\section{Authors' affiliations}

M A Kriegel, J R Kalden, H M Lorenz, Department of Medicine III, Institute for Clinical Immunology and Rheumatology, University of Erlangen-Nuremberg, 91054 Erlangen, Germany
Correspondence to: Dr M A Kriegel, Section of Immunobiology, TAC S560, Yale University School of Medicine, 300 Cedar Street, PO Box 208011, New Haven, CT 06520-8011, USA; martin.kriegel@yale.edu

Accepted 16 May 2004

\section{REFERENCES}

1 Price P, Witt C, Allcock R, Sayer D, Garlepp M, Kok CC et al. The genetic basis for the association of the 8.1 ancestral haplotype (A1, B8, DR3) with multiple immunopathological diseases. Immunol Rev 1999; 167:257-74

2 Sanders DB. Lambert-eaton myasthenic syndrome: diagnosis and treatment. Ann N Y Acad Sci 2003;998:500-8.

3 Wirtz PW, Roep BO, Schreuder GM, van Doorn PA, van Engelen BG, Kuks JB, et al. HLA class I and II in Lambert-Eaton myasthenic syndrome without associated tumor. Hum Immunol 2001;62:809-13.

4 Parsons KT, Kwok WW, Gaur LK, Nepom GT. Increased frequency of HLA class II alleles $\mathrm{DRB} 1{ }^{*} 0301$ and $\mathrm{DQB} 1{ }^{*} 0201$ in Lambert-Eaton myasthenic syndrome without associated cancer. Hum Immunol 2000;61:828-33.

5 Peris P, Del Olme J, Gratacos J, Munoz J. The Lambert-Eaton myasthenic syndrome in association with rheumatoid arthritis. $\mathrm{Br} J$ Rheumatol 1990;29:75-6.

6 Timmermann L, Lindner V, Poepping M, Austermann K, Deuschl G. Idiopathic Lambert-Eaton myasthenic syndrome associated with minimal-change glomerulonephritis and psoriatic arthritis. J Neurol 2001;248:145-7.

7 Deodhar A, Norden J, So Y, Bennett R. The association of systemic lupus erythematosus and Lambert-Eaton myasthenic syndrome. J Rheumatol 1996;23:1292-4

8 Alarcon GS. Unclassified or undifferentiated connective tissue disease. Baillieres Best Pract Res Clin Rheumatol 2000;14:125-37.

9 Lio D, Candore G, Colombo A, Colonna Romano G, Gervasi F, Marino V, et al. A genetically determined high setting of TNF-alpha influences immunologic parameters of HLA-B8, DR3 positive subjects: implications for autoimmunity. Hum Immunol 2001;62:705-13

10 Wirtz PW, Huizinga TW, Stoeken DJ, Wintzen AR, Verschuuren JJ. High innate production of interleukin-10 and tumor necrosis factor-alpha contributes to susceptibility for non-paraneoplastic Lambert-Eaton myasthenic syndrome. J Neuroimmunol 2003;140:194-7.

\title{
Takayasu's arteritis with aortic aneurysm associated with Sweet's syndrome in childhood
}

\author{
L M A Campos, A L Z Castellanos, J Y Afiune, M H B Kiss, C A A Silva
}

S weet's syndrome (SS) is an acute febrile neutrophilic dermatosis, characterised by the appearance of skin lesions and fever, seldom seen in children. ${ }^{12}$ Three reports of SS associated with aortitis in children have been published. Takayasu's arteritis (TA), a vasculitis affecting the aorta and its branches, is quite rare in childhood. Aortic lesions are characterised by stenosis, although aneurysms may be found. ${ }^{34}$ This paper reports the case of a child presenting those two associated diseases, evolving with aortic aneurysm and congestive heart failure (CHF).

\section{CASE REPORT}

A 10 month old female patient presented with fever and crusty erythematous papules, in the trunk and limbs evolving to lax dermis (fig 1). A skin biopsy showed neutrophilic infiltrate in the dermis. Seven months later, the patient presented tachycardia and arthritis in hands, wrists, and ankles.

At admission, her general status was regular, she was pale, weighed $9.9 \mathrm{~kg}$ (2.5-10th centile), her length was $83 \mathrm{~cm}$ (2550 th centile), and she had heart rate of 160 beats/min and respiratory rate of $40 / \mathrm{min}$. Blood pressure was $100 / 40 \mathrm{~mm}$ $\mathrm{Hg}$ in the right arm, 130/70 $\mathrm{mm} \mathrm{Hg}$ in the left arm, 120/ $68 \mathrm{~mm} \mathrm{Hg}$ in the right leg, and $98 / 40 \mathrm{~mm} \mathrm{Hg}$ in the left leg. Peripheral pulses were wide and symmetric. Cardiac examination disclosed a diastolic murmur at the left sternal margin. Laboratory tests showed haemoglobin $91 \mathrm{mg} / \mathrm{l}$, leucocytes $14 \times 10^{9} / \mathrm{l}$, erythrocyte sedimentation rate $57 \mathrm{~mm} /$ lst $h$, and a negative Mantoux test. Echocardiography showed severe aortic insufficiency (AoI) and marked dilatation of the aorta. Angioresonance showed dilatation of the ascending aorta (30 mm), aortic arch $(27 \mathrm{~mm})$, and descending aorta $(15 \mathrm{~mm})$; dilatation and stenosis in the brachiocephalic branch, common carotid, and left subclavian arteries (fig 1); and the abdominal aorta and iliac caliber were decreased, with wall irregularities.

During hospitalisation, the patient presented a decrease of left upper limb pulses and ischaemia of left hand fingers. The diagnosis of TA and SS was made. Treatment was started with intravenous gammaglobulin $(2 \mathrm{~g} / \mathrm{kg} / \mathrm{monthly})$ and intravenous pulse methylprednisolone $(30 \mathrm{mg} / \mathrm{kg}$ ) for 3 days, monthly, followed by oral prednisone $(2 \mathrm{mg} / \mathrm{kg} /$ day $)$, progressively decreased to $10 \mathrm{mg} / \mathrm{day}$.

Seven months later, the patient was clinically stable, the erythrocyte sedimentation rate was $24 \mathrm{~mm} / \mathrm{lst} \mathrm{h}$, and angioresonance showed unaltered findings in the thorax, with normalisation of abdominal aorta.

\section{DISCUSSION}

Sweet's syndrome is an acute febrile neutrophilic dermatosis, seldom seen in infancy, characterised by fever and appearance of erythematous painful nodules, plaques, and/or 

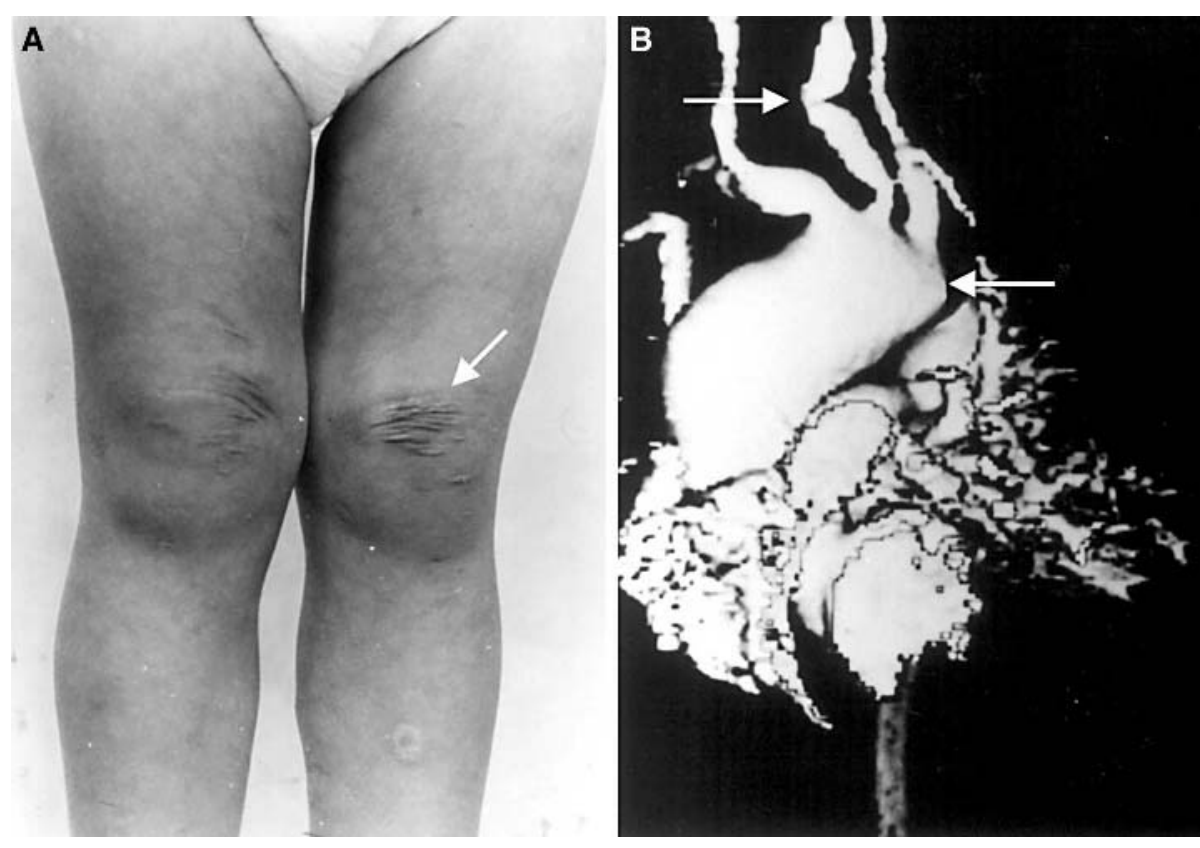

Figure 1 (A) Lax dermis (Sweet's syndrome); (B) stenotic and aneurysmatic lesions affecting the aorta and its bronches.

papules distributed over the face, trunk, and limbs. It may be associated with systemic manifestations, such as cardiovascular system abnormalities, pulmonary and renal failure. Such a syndrome has been connected with a number of rheumatic diseases, such as dermatomyositis, Sjögren's syndrome, Behçet's disease, and TA. Its cause and pathogenesis are still unknown. Autoimmune and infectious factors seem to be involved. ${ }^{12}$

Arthralgia and/or arthritis are seen in about 33\% of adult patients. Tuerlinckx et al described the case of SS in a 4 month old boy, which evolved with monarthritis of the right knee, improving after the use of systemic and intraarticular corticosteroids. ${ }^{5}$ This is the second case to present such clinical manifestations in a child.

This case presented SS associated with TA with severe involvement of the aorta and its branches. Three cases reports of aortitis associated with SS in children have been published. ${ }^{67}$ In all of them, skin lesions evolved to scars, characterising lax dermis. Vascular symptoms and signs may be insidious for long periods. Muster et al described the case of a 16 month old baby girl diagnosed as having SS with pulmonary involvement, who improved after receiving systemic corticotherapy. After 14 months of treatment, the patient presented ascending aorta aneurysm, AoI, and coronary stenosis, and finally died. ${ }^{7}$ The anatomopathological study showed similar histological findings in skin lesions and lesions in the aorta, leading us to question whether aortitis is part of SS. Other authors believe that vascular abnormalities found in such patients fulfil the criteria of TA.

TA is a chronic inflammatory disease, affecting the aorta and its branches. In Japan, $20 \%$ of cases were found in patients aged less than 19 and just $2 \%$ in children aged less than 10 years. The American College of Rheumatology classification criteria are applicable to the paediatric group. CHF is connected with arterial hypertension, myocarditis, pericarditis, pulmonary hypertension, and AoI. Aortic insufficiency affects $7-55 \%$ of patients with TA, being more prevalent among patients with aneurysms. ${ }^{8-10}$ The patient described presented CHF, probably secondary to arterial hypertension and AoI.
Another major problem presented by this patient was the presence of aneurysms in several aortic segments and branches. In childhood, vasculitis is an important cause of aneurysms, mainly Kawasaki disease and TA. Aneurysms have been reported in $2-33 \%$ of patients with TA, normally associated with stenosis. Aneurysms and AoI are considered to provide the worst prognosis for TA evolution. ${ }^{10}$

The reported case presents the association of two rare diseases in an infant, with manifestations seldom seen, such as lax skin, arthritis, aneurysms, and aortic insufficiency.

\section{Authors' affiliations}

L M A Campos, A L Z Castellanos, J Y Afiune, M H B Kiss, C A A Silva, Instituto da Criança, Hospital das Clínicas, University of São Paulo Medical School, Brazil

Correspondence to: $\operatorname{Dr}$ L M A Campos, Rua Tucuman 177 apto $181 \mathrm{~b}$ São Paulo, SP, Brazil 01455-010; barcelos.ops@terra.com.br

Accepted 7 April 2004

\section{REFERENCES}

1 Tradwel PA. Selected systemic diseases with skin manifestations. In:Schachner LA, Hansen RC. Pediatric dermatology. New York: Churchill Livingstone, 1995: 1163-5.

2 Cohen PR, Kurzrock R. Sweet's syndrome: a neutrophilic dermatosis classically associated with acute onset and fever. Clin Dermatol 2000;18:265-82.

3 Kerr GS. Takayasu's arteritis. Rheum Dis Clin North Am 1995;21:1041-57.

4 Keystone EC. Takayasu's arteritis. In: Klippel JH, Dieppe PA. Rheumatology. London: Mosby, 1998:7.25.1-4.

5 Tuerlinckx D, Bodart E, Despotin K, Boutsen Y, Godding V, Ninane J. Sweet's syndrome with arthritis in an 8 month old boy. J Rheumatol 1999;26:440-2.

6 Guia JM, Frias J, Castro FJ, Gracián M. Cardiovascular involvement in a boy with Sweet's syndrome. Pediatr Cardiol 1999;20:295-7.

7 Muster AJ, Bharati S, Herman JJ, Esterly NB, Gonzales-Crussi F, Holbrook KA. Fatal cardiovascular disease and cutis laxa following neutrophilic dermatosis. $J$ Pediatr 1983;102:243-8.

8 Sharma BK, Jain S, Sagar S. Systemic manifestations of Takayasu's arteritis: the expanding spectrum. Int J Cardiol 1996;54(suppl): 121-6.

9 Matsumura K, Hirano T, Takeda K, Matsuda A, Nakagawa T, Yamaguchi N, et al. Incidence of aneurysm in Takayasu's arteritis. Angiology $1991 ; 42: 308-15$

10 Kumar S, Subramanyan R, Mandalam KR, Rao VRK, Gupta AK, Joseph S, et al. Aneurysmal form of aortoarteritis (Takayasu's disease): analysis of thirty cases. Clin Radiol 1990;42:342-7. 